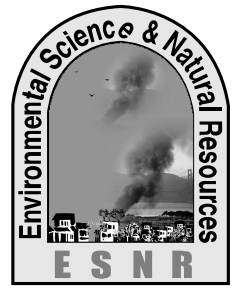

\title{
Effects of Pre-drying Chemical Treatments on Quality of Cabinet Dried Tomato Powder
}

\author{
N. H. M. R. Mozumder ${ }^{1}$, M. A. Rahman ${ }^{2}$, M. S. Kamal ${ }^{3}$, A. K. M. Mustafa ${ }^{4}$ and \\ M. S. Rahman \\ ${ }^{1}$ Department of Food Science and Nutrition, ${ }^{2}$ Department of Food Processing and Preservation \\ ${ }^{5}$ Department of Agricultural and Industrial Engineering, \\ Hajee Mohammad Danesh Science and Technology University \\ ${ }^{3}$ Department of Food Technology and Rural Industries, Bangladesh Agricultural University, Mymensingh \\ ${ }^{4}$ QC Officer, Siddique Food Industries Bangladesh Ltd, Dhaka
}

\begin{abstract}
The focus of this research was to analyze the yield, physico-chemical and nutritional quality of a cabinet dried tomato powder as affected by three (3) chemical treatments (KMS, $\mathrm{CaCl}_{2}$ and both). Dehydration process was carried out using a cabinet dryer at a constant air flow velocity of $0.7 \mathrm{~m} / \mathrm{s}$ and air temperature in the range of $60-65^{\circ} \mathrm{C}$ based on preliminary tests by dipping in $0.2 \%$ $(\mathrm{w} / \mathrm{w})$ potassium metabisulphite $\left(\mathrm{T}_{1}\right)$ and $1 \%(\mathrm{w} / \mathrm{w})$ calcium chloride $\left(\mathrm{T}_{2}\right)$ independently and $1 \%(\mathrm{w} / \mathrm{w})$ calcium chloride $\left(\mathrm{CaCl} \mathrm{Cl}_{2}\right)$ along with $0.2 \%(\mathrm{w} / \mathrm{w})$ potassium metabisulphite (KMS) in water solution $\left(\mathrm{T}_{3}\right)$ for 10 minutes. The effect of 3 pre-drying treatments on quality of cabinet dried tomato powder was analyzed by determining moisture content, rehydration ratio, total sugar, total acidity, fat, protein, ash, crude fiber, $\mathrm{pH}$, total caroteniods, vitamin-C, minerals (calcium, iron, phosphorus) and sensory analysis. The results expressed that the treatment $T_{3}$ achieved the highest yield of tomato powder $(4.6 \mathrm{~g} / 100 \mathrm{~g})$. The control sample showed highest moisture content $(6.9 \mathrm{~g} / 100 \mathrm{~g})$ and dipping in $1 \% \mathrm{CaCl}_{2}$ along with $0.2 \% \mathrm{KMS}$ presented the lowest moisture content $(5.9 \mathrm{~g} / 100 \mathrm{~g})$. Sample $\mathrm{T}_{3}$ showed highest total sugar content $(49.1 \mathrm{~g} / 100 \mathrm{~g})$. The study also depicted that the total carotenoids content in tomato powder was $0.21 \mathrm{mg} / 100 \mathrm{~g}$ which was lower than that of fresh tomato $(2.1 \mathrm{mg} / 100 \mathrm{~g})$. Micronutrients such as vitamin-C, Calcium, phosphorus and iron were found to be $35.30 \mathrm{mg} / 100 \mathrm{~g}, 336.72 \mathrm{mg} / 100 \mathrm{~g}, 105 \mathrm{mg} / 100$ $\mathrm{g}$ and $12.23 \mathrm{mg} / 100 \mathrm{~g}$, respectively in case for $\mathrm{T}_{3}$ sample. Sensory analysis (color, texture, flavor and overall acceptability) of tomato powder was carried out by trained and untrained panelists and their interpretation was done by using statistical ANOVA Test. There was no significant difference between control and treated samples regarding to their texture, flavor and overall acceptability but significant difference was observed in case of color.
\end{abstract}

Keywords: ANOVA, Cabinet drying, KMS, Pre-treatment, Tomato powder

\section{Introduction}

Tomato (Lycopersicon esculantum L.) belongs to the family of Solanaceae, and is one of the most widely consumed fresh vegetables in the world. Tomatoes are rich source of lycopene $(60-90 \mathrm{mg} / \mathrm{kg})$, polyphenols $(10-50 \mathrm{mg} / \mathrm{kg})$ and small quantities of vitamin E $(5-20 \mathrm{mg} / \mathrm{kg})$ and also a nutritionally recognized vegetable for their vitamin $\mathrm{C}$ content, with an average tomato supplying about $40 \%$ of the adult United States Recommended Daily Allowances (RDA) of $60 \mathrm{mg}$ (Charanjeet et al., 2004). There is a rapid development of tomato processing industries in recent decades with a series of interlinked activities such as production of salad, soup, juice, puree, paste and powder and extraction of oil from the pulp and the demand for dehydrated tomato is increasing rapidly both in domestic and in international market with major portion of it being used for preparation of convenience food since it has limited shelf life and highly perishable at ambient conditions (Purseglove et al., 2001). Moreover, in 2001 the US produced 11.6 million metric tons of processing tomatoes, worth \$ 913 milion and Brazil produces more than 3.7 million tons of tomato annually, with total farm to table losses of up to 40\% (Lewicki et al., 2002; Latapi and Barrett, 2006) and in Bangladesh tomato was grown in 44,275 acres of land with the production of approximately 190,213 metric ton in 2009-2010 (BBS, 2010).

Presently, fresh tomato products are being processed and marketed in Bangladesh in the form of puree, paste, catch-up, sauce, pickles, chutney (Sharfuddin and Siddique, 2000) etc but interest in the production of dehydrated tomato product in all over the world is increasing due to the possibility of using them in pizza toppings, snacks and other savoury dishes (Gisele et al., 2004; Lewicki et al., 2002).

Processing of tomatoes using sun drying with cut pieces, drying of whole tomatoes, spray drying and convection drying using solar or mechanical systems has been used for many years (Baloch et al., 1997; Collins et al., 1997; Hawlader et al., 1991; Olorunda, et al., 1990; Shi et al., 1999; Zanoni et al., 1999). Traditional sun-drying is a slow process compared with other drying methods and quality losses may result from high moisture content, color degradation by browning, microbial growth (Okos et al., 1992; 
Lewicki et al., 2002). Sun drying requires 7 to 12 days, and results in a product with typically $12 \%$ to $24 \%$ moisture and robust taste. Sun-dried tomatoes darken during storage, which is typically 9 to 12 months (Ecom, 1997). Scientific literature on methods for improving the quality of dehydrated tomatoes through modification of the traditional process or incorporation of pretreatments is limited and variable. Therefore, there has been a rapid stimulation to search for new alternatives that comprises of manipulation and addition of chemical preservatives/additives more specifically pre-treated with pre-drying chemicals (Latapi and Barrett, 2006)

Pre-treatments with chemicals before drying have been used in order to minimize adverse changes during drying and subsequent storage tomatoes. The most common and least expensive method to prevent enzymatic browning in fresh prepared vegetables or tomatoes is by the use of sulphiting or salt agents such as metabisulphite and or calcium chloride since they have multiple functions (Roy and Choudary, 1972). Traditionally, tomatoes are dehydrated after a pretreatment with sulfur dioxide, in closed chambers either by burning sulfur or gassing with sulfur from a cylinder (Valley Sun, 2000). Another method for introducing of sulfur dioxide into the tomato is by dipping in sodium metabisulfite solutions (Pazyr et al., 1996).

Presently, there are few published studies comparing the single or mixed effects of calcium chloride and sodium metabisulfite dipping treatments on quality parameters of cabinet-dried tomatoes. Hence, the objective of this study was to evaluate the effects of 3 pretreatments on various qualities of cabinet dried tomatoes including: total sugar, acidity, fat, protein, ash, crude fiber, $\mathrm{pH}$, total caroteniods, vitamin-C, minerals (calcium, iron, phosphorus) and sensory analysis and to determine the influence of cabinet driers on pretreated dehydrated powder.

\section{Materials and Methods}

\section{Experimental location and time}

The study was conducted in the laboratory of the Department of Food Processing and Preservation under the Faculty of Agro-Industrial and Food Process Engineering, Hajee Mohammad Danesh Science and Technology University, Dinajpur in collaboration with laboratory of Food Enzymolozy Section, Vegetable Technology Section, Fruit Technology Section and Applied Nutrition Section under the Institute of Food Science and Technology of Bangladesh Council of Science and Industrial Research, Dhaka during the year of 2011.

\section{Materials \\ Chemicals and raw materials}

The chemicals such as sodium hydroxide $(\mathrm{NaOH})$, sodium chloride $(\mathrm{NaCl})$, hydrochloric acid $(\mathrm{HCl})$, petroleum ether, copper sulphate $\left(\mathrm{CuSO}_{4} .5 \mathrm{H}_{2} \mathrm{O}\right)$, ammonium sulphate, boric acid used in this research work were obtained from E. Merck (West Germany) and Nitric acid $\left(\mathrm{HNO}_{3}\right)$ Sulphuric acid $\left(\mathrm{H}_{2} \mathrm{SO}_{4}\right)$ were obtained from British Drug House (England). The tomatoes of var. hybrid were collected from the harvesting filed located at Gabura in Dinajpur district during the period of April, 2011. The collected tomatoes were fresh, ripe, fully matured and 60-75 $\mathrm{mm}$ in average diameter and with an average weight of 90-110 gm. After collection, they were stored at room temperature $\left(25 \pm 2^{\circ} \mathrm{C}\right)$ and then sorted and washed with distilled water to remove dirt and soil; further tomatoes were cut into slices (from steam scar to blossom end) with thickness of $5 \mathrm{~mm}$ by using a stainless steel knife.

\section{Methods}

Pre-treatments with chemical (KMS and CaCl) before dehydration process

The Tomato slices were pre-treated by dipping in 3 different chemical solutions according to the method as followed by Ghavidel and Davoodi (2010) as presented in Table 1 and Figure 1 as follows: a) Dipping $1 \mathrm{gm} / 100 \mathrm{gm}$ of $\mathrm{CaCl}_{2}$ in water solution $(1: 1$ w/w) at room temperature for 10 minutes. b) Dipping KMS $0.2 \mathrm{gm} / 100 \mathrm{gm}$ solution at room temperature for 10 minutes. c) Dipping in $1 \mathrm{gm} / 100 \mathrm{gm} \mathrm{CaCl}_{2}$ in combination with $0.2 \mathrm{gm} / 100 \mathrm{gm} \mathrm{KMS}$ in an equal mass of water for 10 minutes. d) Tomatoes slices dipped in an equal an equal mass of plain water for 10 minutes at room temperature were considered as controlled sample Ghavidel and Davoodi (2010). 

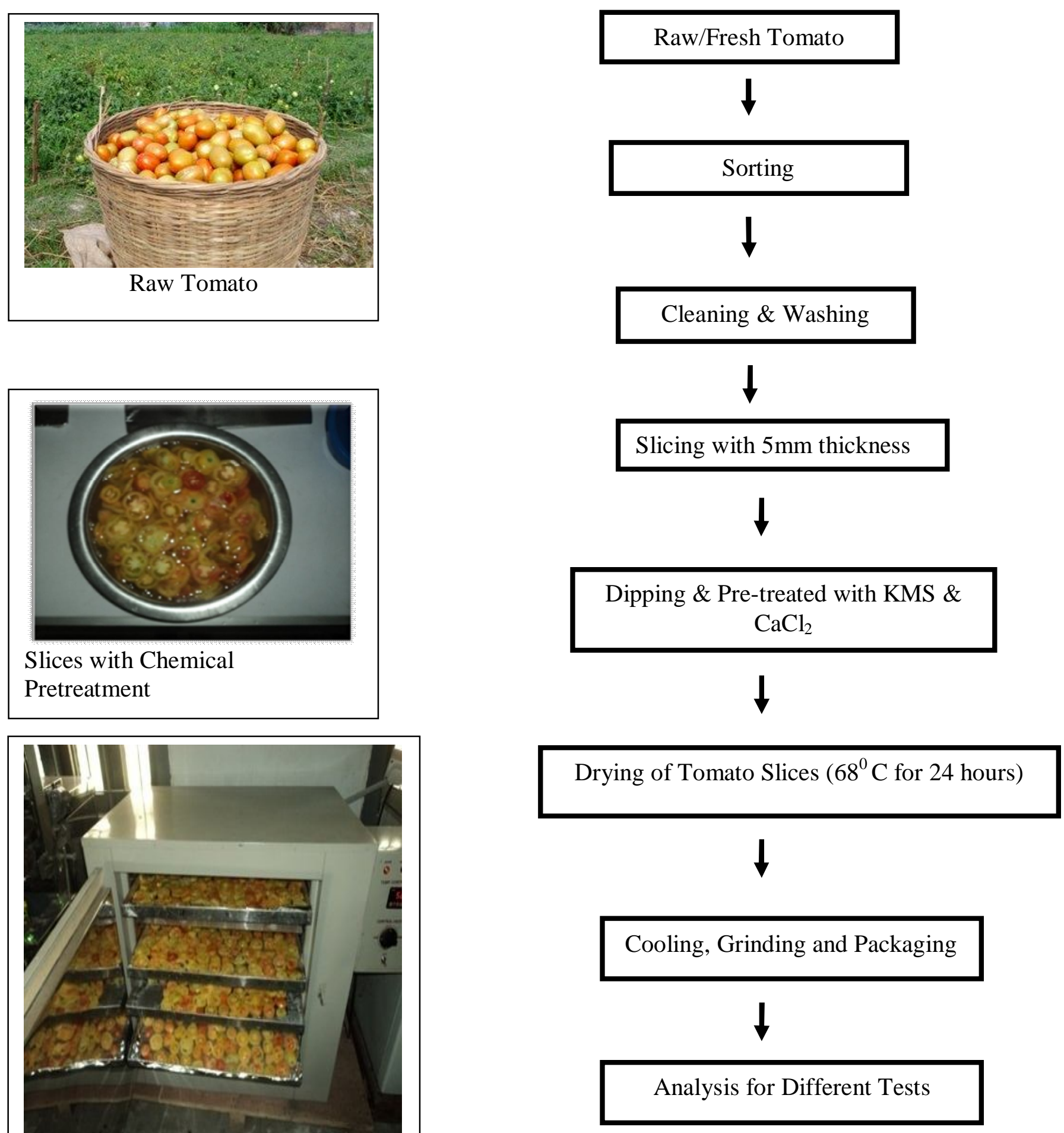

Drying with Cabinet Dryer

Fig. 1. Process flow chart of tomato dehydration process 
Table. 1. Experimental design for studies on effects of chemical pre-drying treatments on cabinet dried tomato powder

\begin{tabular}{|c|c|c|c|c|}
\hline Treatment & $\begin{array}{c}\text { Concentration of Pre-drying } \\
\text { treatments }\end{array}$ & & \multicolumn{2}{|c|}{ Studied parameters } \\
\hline $\mathrm{T}_{1}$ & $0.2 \% \mathrm{KMS}(1: 1 \mathrm{w} / \mathrm{w})$ & & \multirow{3}{*}{\multicolumn{2}{|c|}{$\begin{array}{l}\text { Moisture, rehydration ratio/ } \\
\text { capacity, drying curves, physic- } \\
\text { chemicals and shelf life and } \\
\text { sensory analysis }\end{array}$}} \\
\hline $\mathrm{T}_{2}$ & $1 \% \mathrm{CaCl}_{2}(1: 1 \mathrm{w} / \mathrm{w})$ & & & \\
\hline $\mathrm{T}_{3}$ & $\begin{array}{c}0.2 \% \mathrm{KMS}+1 \% \mathrm{CaCl}_{2}(1: 1 \\
\mathrm{w} / \mathrm{w})\end{array}$ & & & \\
\hline $\mathrm{T}_{0}$ & Control in plain water & & & \\
\hline \multicolumn{5}{|c|}{$\begin{array}{l}\text { *Dipping time was } 10 \text { min. } \\
* 1000 \mathrm{~g} \text { fresh tomato was used }\end{array}$} \\
\hline Treatment & $\begin{array}{c}\begin{array}{c}\text { Concentration of Pre-drying } \\
\text { treatments }\end{array} \\
\end{array}$ & $\begin{array}{l}\text { Tomato Powder } \\
(\mathrm{gm})\end{array}$ & $\begin{array}{l}\text { Dry matter }^{\mathrm{a}} \\
(\%)\end{array}$ & $\begin{array}{c}\text { Water loss }{ }^{\mathrm{a}} \\
(\%)\end{array}$ \\
\hline $\mathrm{T}_{1}$ & $0.2 \% \mathrm{KMS}(1: 1 \mathrm{w} / \mathrm{w})$ & 38.27 & 3.83 & 96.17 \\
\hline $\mathrm{T}_{2}$ & $1 \% \mathrm{CaCl}_{2}(1: 1 \mathrm{w} / \mathrm{w})$ & 46.1 & 4.60 & 95.40 \\
\hline $\mathrm{T}_{3}$ & $\begin{array}{c}0.2 \% \mathrm{KMS}+ \\
1 \% \mathrm{CaCl}_{2}(1: 1 \mathrm{w} / \mathrm{w})\end{array}$ & 43.6 & 4.36 & 95.64 \\
\hline $\mathrm{T}_{0}$ & Control in plain water & 40.9 & 4.09 & 95.91 \\
\hline
\end{tabular}

${ }^{\mathrm{a}}$ All means are based on triplicate values

\section{Dehydration process using cabinet dryer: preparation of tomato powder}

The pre-treated tomato slices were used for dehydration using air convection drying techniques as described by Narsing Rao et al. (2008). The pretreated tomato slices were dried in the cabinet drier (Figure 1). A cabinet dryer (136-120, Seoul, Korea) was used for the dehydration experiments. The tomatoes were placed uniformly on stainless steel trays by spreading the slices at an area interval of $1.25 \mathrm{lb} / \mathrm{ft}$ square as a single layer (loading density) and experiments were conducted at $60-65^{\circ} \mathrm{C}$ air temperatures and at a constant airflow velocity of $0.7 \mathrm{~ms}^{-1}$ for $24 \pm 2$ hours. In each experiment, about $10 \mathrm{~kg}$ of tomato slices in each tray were dried. Weight losses (thus moisture content) of sample during drying process was determined by gravimetric method after each 4 hours interval and continued until no further weight changes were observed. After cooling at room temperature, the dried tomato flakes were ground by using blender to produce tomato powder. The tomato powder was then packaged in low density polyethylene bags (LDPE) for further investigation or analytical research.

\section{Quality characteristics of dehydrated tomato dehydration ratio (DR)}

Dehydration ratio was calculated as mass of sliced tomato before loading to the drier to mass of dehydrated material at the time of removal from drier (Sebii et al., 2002).

\section{Rehydration ratio $(R R)$}

The rehydration test was carried out as followed (Lewicki, 1998; Levi et al., 1988). Two grams (2g) of tomato powder was weighed (initial weight) into $250 \mathrm{ml}$ beakers and submerged in $50 \mathrm{ml}$ distilled water at room temperature for $0.5,1.0,1.5,2.0$ etc hours and the samples were drained by vacuum pump until all the water was drained out and the adhered water was absorbed by tissue paper and finally weight of rehydrated sample was taken (final weight). The rehydration ratio was obtained by dividing the rehydrated weight by the initial weight.

Determination of $P^{H}$

The $\mathrm{pH}$ of the selected samples was determined by a $\mathrm{pH}$ meter (Hanna instruments- ORPP), salinity-sodium tester (ISO-9001 certified company; Woonsocket, RI 02895) with the supplied $\mathrm{pH} 4.0$ buffer solution, distilled water and 50 $\mathrm{ml}$ beakers.

\section{Estimation of proximate compositions}

Proximate analysis of dehydrated tomato powder for moisture, ash, crude fat (solvent extraction), crude protein (Kjeldahl $\mathrm{N} \times 6.25$ ), and crude fiber were determined in at least triplicate using the methods as described by AOAC (AOAC, 1984).

\section{Estimation of moisture content}

The moisture content was determined according to the AOAC (1984) method. Five (5) g of samples was accurately weighed into dried crucible and placed in an oven (Mettler Toledo, $\mathrm{AB}$ 104) at $105 \pm 2^{\circ} \mathrm{C}$ for 4 (four) hours. After drying, the samples were removed from the oven and placed in desiccators to cool for about 30 minutes and then reweighed. The process of evaporation, cooling and weighing process were repeated until constant weight was found. 


\section{J. Environ. Sci. \& Natural Resources, 5(1): 253-265, 2012}

Table 3. Quality Parameters of Dehydrated Tomato by different chemical and physical analysis

\begin{tabular}{|c|c|c|c|c|c|c|c|c|c|c|c|c|c|c|}
\hline \multirow[t]{2}{*}{ Treatment } & \multicolumn{7}{|c|}{ Proximate composition ( $\mathrm{g} / 100 \mathrm{~g}$ of dried sample) } & \multicolumn{3}{|c|}{$\begin{array}{c}\text { Minerals } \\
(\mathrm{mg} / 100 \mathrm{~g} \text { of dried sample) }\end{array}$} & \multirow{2}{*}{$\begin{array}{c}\text { Total } \\
\text { Carotenoids } \\
(\mu \mathrm{g} / 100 \mathrm{~g})\end{array}$} & \multirow{2}{*}{$\begin{array}{c}\text { Dehydration } \\
\text { Ratio } \\
\text { (DR) }\end{array}$} & \multirow[t]{2}{*}{$\begin{array}{l}\text { Acidity } \\
\text { (g/100g) }\end{array}$} & \multirow[t]{2}{*}{$\mathrm{pH}$} \\
\hline & Moisture & Total sugar & Fat & Protein & Ash & Crude fiber & Vitamin-C & $\mathrm{Ca}$ & $\mathrm{Fe}$ & $\mathrm{P}$ & & & & \\
\hline $\mathrm{T}_{1}$ & 6.1 & 48.7 & 2.8 & 13.1 & 10.21 & 6.1 & ND & ND & ND & ND & ND & 15.03 & 5.86 & 4.21 \\
\hline $\mathrm{T}_{2}$ & 6.5 & 48.1 & 2.8 & 12.6 & 10.36 & 6.3 & ND & ND & ND & ND & ND & 14.67 & 6.28 & 4.40 \\
\hline $\mathrm{T}_{3}$ & 5.9 & 49.1 & 3.0 & 13.9 & 10.72 & 6.5 & 35.30 & 336.672 & 12.23 & 105 & 210 & 14.38 & 6.05 & 4.25 \\
\hline $\mathrm{T}_{0}$ & 6.9 & 47.9 & 2.2 & 13.1 & 10.25 & 5.9 & ND & ND & ND & ND & ND & 15.50 & 6.12 & 4.20 \\
\hline
\end{tabular}

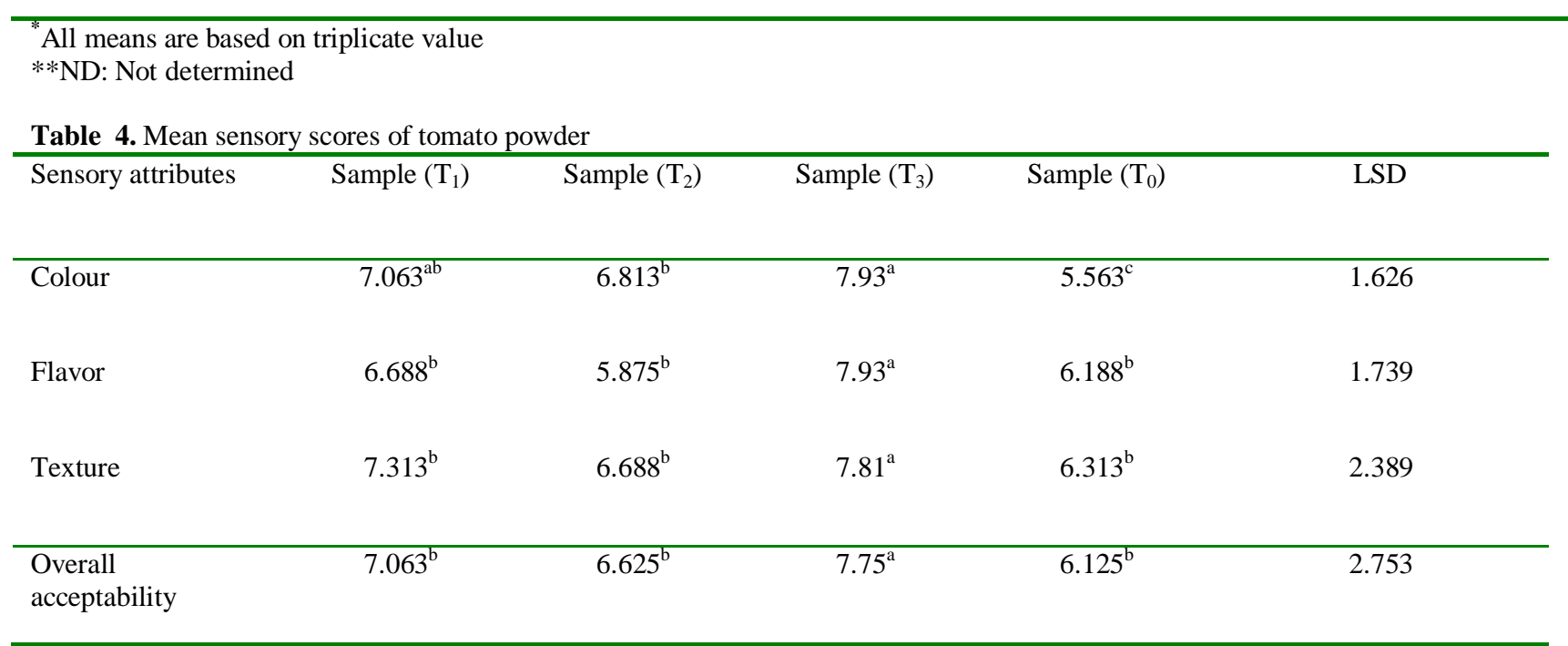

*Means with same superscript within a color are not significantly different at $\mathrm{P}<0.05$

$*$ Sample $\left(\mathrm{T}_{3}\right)=$ Powder from $1 \% \mathrm{CaCl}_{2}+0.2 \% \mathrm{KMS}$ treated

$*$ Sample $\left(\mathrm{T}_{1}\right)=$ Powder from $0.2 \% \mathrm{KMS}$ treated

$*$ Sample $\left(\mathrm{T}_{2}\right)=$ Powder from $1 \% \mathrm{CaCl}_{2}$ treated

$*$ Sample $\left(\mathrm{T}_{0}\right)=$ wi 


\section{Estimation of total ash}

The ash was determined by the method as reported in the handbook of AOAC (1984). samples were weighed (5g) accurately in a previously cleaned and dried- weighed crucible. At first the crucible containing sample was placed in an oven $\left(100-105^{\circ} \mathrm{C}\right)$ for $4 \mathrm{hrs}$ to remove moisture. The moisture free sample was completely charred (free from carbon residues: appears in grayish-white) in a heating mantel followed by heating (ashing) in a muffle furnace at $600^{\circ} \mathrm{C}$ for 3 hours. Then it was removed from furnace and cooled in desiccators and weighed. To ensure complete ashing, the crucible was again heated in a muffle furnace for one hour. Then this was removed from the furnace and cooled in desiccators and weighed again.

\section{Estimation of protein content}

$200 \mathrm{mg}$ of oven dried ground pulse sample was placed in a Microkjeldahl digestion flask. 500-600 $\mathrm{mg}$ of digestion mixture (catalyst) and $5 \mathrm{ml}$ of concentrated sulphuric acid were added into the flask. The flask was cautiously heated on a digestion rack for one hour until a greenish clear digest appeared. The clear digest was allowed to cool and then dissolved in minimum amount of distilled water (5-10 $\mathrm{ml}$ ) and carefully transferred to a Microkjeldahl distillation set. To the digested sample in the apparatus, $20 \mathrm{ml}$ of 40 percent $\mathrm{NaOH}$ solution was added through funnel stopcock. Distillation commenced immediately by closing the steam bypass and opening the inlet stopcock on the steam jet arm of the distillation apparatus. The distillate was collected for 5 minutes in a $50 \mathrm{ml}$ receiver flask containing 2 drops of mixed indicator and $20 \mathrm{ml}$ boric acid till the color of the solution changes. The distillate was titrated against a standard $\mathrm{HCl}$ solution and the titrated volume (TV) was noted.

\section{Estimation of crude fat (ether extract) content}

Five grams $(5 \mathrm{~g})$ of previously ground and dried pulse sample was placed in a thimble plugged with cotton. The thimble with its contents was transferred to a Soxhlet extractor (Gerhardt) and extracted with ethyl ether for 16 hours. At the completion of the extraction, the ether or fat extract was transferred from the extraction flask into a pre-weighed conical flask with 4-6 times rinsing of ethyl ether. The ether was then removed by evaporation and the flask with the residue dried in an oven at $100^{\circ} \mathrm{C}$ for 30 minutes.

\section{Estimation of crude fiber content}

Moisture and fat free sample (5g) was poured into a cleaned and oven dried $500 \mathrm{ml}$ beaker containing 200 $\mathrm{ml}$ of pre- heated sulphuric acid $(0.255 \mathrm{~N})$. The mixture was boiled for 30 minute keeping the volume constant by the addition of distilled water at frequent interval. The mixture was then filtered through muslin cloth and the residue was washed several times with hot water until it was made acid free. The residue was then transferred into a $500 \mathrm{ml}$ clean and dry beaker containing $200 \mathrm{ml}$ of pre-heated $\mathrm{NaOH}$ $(.0313 \mathrm{~N})$ and boiled for 30 minutes. After boiling the mixture was filtered through a muslin cloth and the residue was washed several times with hot water followed by washing with alcohol and then ether until the sample was made alkali free. This alkali free sample was then dried in an oven at $105^{\circ} \mathrm{C}$ for four hours, cooled in a desiccator and weighed (a). Next this crucible was heated in a muffle furnace at $600^{\circ} \mathrm{C}$ for 3-4 hours, cooled and weighed again (b). This difference in the weights (a-b) represents the weight of crude fiber present in the sample.

\section{Determination of total sugar}

Sugar content of tomato powder was determined according to Lane and Eyanon (1923). An amount of $25 \mathrm{ml}$ of the standard invert solution was pipette into a $100 \mathrm{ml}$ volumetric flask and about $50 \mathrm{ml}$ of water was added. A few drops of phenolphthalein indicator was added and neutralized with $20 \% \mathrm{NaOH}$ until the solution turned pink. Then acidity with $1 \mathrm{~N} \mathrm{HCI}$ was added drop wise until one drop caused the pink to mark with water $(1 \mathrm{~mL}=25 \mathrm{mg}$ of invert sugar $)$.

\section{Total sugar}

An amount of $50 \mathrm{ml}$ of the clarified solution was pipette into a $100 \mathrm{ml}$ conical flask and to it $2 \mathrm{gm}$ of citric acid was added and was boiled gently for 10 minutes to complete the inversion of sucrose and was cooled and transferred to a $100 \mathrm{ml}$ volumetric flask. The solution was neutralized with $1 \mathrm{n} \mathrm{NaOH}$ using phenolphthalein as indicator. For inversion at room temperature $\left(20^{\circ} \mathrm{C}\right.$ or above) for 24 hours and then neutralized with concentrated $\mathrm{NaOH}$ solution and volume was made up to $100 \mathrm{ml}$.

\section{Estimation of mineral content by dry ashing method} The minerals were analyzed from solutions obtained by fits' dry-ashing the powder of tomato. About $0.5 \mathrm{~g}$ of dried samples was transferred into a crucible and ashed in a muffle furnace at $600^{\circ} \mathrm{C}$ for 3 hours. The ash obtained was boiled with $12.5 \mathrm{ml}$ hydrochloric acid in a beaker, filtered into a $100 \mathrm{ml}$ volumetric flask and made up to the mark with distilled water. Phosphorus was determined by using spectrophotometer (JASCO V-630). All determinations were done in triplicate. For phosphorus determination, $2 \mathrm{ml}$ of Ammonium Molybdate vanadate and $5 \mathrm{ml}$ of $5 \mathrm{M}$ hydrochloric acid were added to $2 \mathrm{ml}$ of the stock solution. The concentration of phosphorus was determined through 
the measurement of the yellow phosphor vanadomolybdate complex using Cecil Carating Digital Spectrophotometer Series

\section{Determination of vitamin-C}

Vitamin-C was determined by the titration method as described by Rangana (1992). For this, $10 \mathrm{ml}$ of sample was taken in a volumetric flask and made up to the volume $100 \mathrm{ml}$ with 3\% Meta phosphoric acid and filtered. Pipette $10 \mathrm{ml}$ of filtrate into a conical flask and titrated with the standard dye solution to a pink end-point.

\section{Determination of total carotenoids}

Total Carotenoids was determined according to Delia et al. (2004). Total Carotenoid contents for all the samples under study were estimated by the standard procedure followed in harvest plus research (Delia et al., 2004). Here we used spectrometric method to estimate total Carotenoid content in samples.

\section{Organoleptic evaluation of dehydrated tomato}

After the preparation of tomato powder, 4 samples were selected for organoleptic evaluation according to the method as described by Stone (1985). The Organoleptic evaluations of tomato powder were carried out by 10 judges. All the judges formed the panel were conversant with the factor governing the quality of the sample. Tomato powder was evaluated organoleptically for color, flavor, texture and overall acceptability. The taste panelists were asked to rate the samples for color, flavor, texture and overall acceptability on 1-9 point hedonic scale, when, $9=$ like extremely; $8=$ like very much; 7=like moderately; 6=like slightly; $5=$ neither like nor dislike; 4=dislike slightly; $3=$ dislike moderately; $2=$ dislike very much; $1=$ dislike extremely.

\section{Results and Discussion}

\section{Effect of pretreatments on dehydration process efficiency}

The effect of different pretreatments on dehydration process efficiency or percent yield of (solids gain or water loss) tomato powder is presented in Table 1 and Fig.2. From the table and figure, sit can be seen that higher efficiency (solid content 4.6\%) was obtained when the raw tomatoes pretreated with Calcium Chloride $\left(\mathrm{CaCl}_{2}\right)$ along with Potassium Metabisulphite (KMS) than the tomatoes pretreated with $\mathrm{CaCl}_{2}(4.36 \%)$ and $\mathrm{KMS}(3.83 \%)$. The control samples which were not pretreated reported only $4.09 \%$ recovery. Narsing Rao et al. (2008) reported that drying of $24 \mathrm{~kg}$ of fresh mature ripe tomatoes achieved $1.38 \mathrm{~kg}(5.75 \%)$ of dried tomato powder which was higher than that of our values. The reason of higher efficiency might be due to the interactions of chemicals (salt and preservatives) and constituents of tomato.

\section{Drying characteristics}

The moisture contents of various chemically pretreated tomato samples were studied and drying rate curves as a function of drying time at constant temperature for dehydrated tomato pre-treated $0.2 \%$ KMS plus $1 \% \mathrm{CaCl}_{2}$ and control sample were plotted (Fig. 3) based on their higher dehydration efficiency. There was an initial moisture content of $95 \% \pm 1$ in fresh tomatoes during the initial phase of drying and with the increases of time the final moisture content was reduced to $6-7 \%$ for sample treated $0.2 \% \mathrm{KMS}$ plus $1 \% \mathrm{CaCl}_{2}$ with until no further changes in their mass were observed. The times needed to reach the final moisture content for treated and non-treated samples were $24 \pm 2$ hours. The drying rate curve was identical and similar to previous study as reported by Hema et al. (2007). In the early period of drying, there was a rapid decline in the moisture content for all the pieces of tomatoes. As expected the drying time decreased considerably with an increase in the air temperature.

\section{Quality characteristics of dehydrated tomato}

The characteristics of dehydrated tomato powder as affected by pre-drying treatment are presented in Table 2. Sample pre-treatment with Calcium Chloride $\left(\mathrm{CaCl}_{2}\right)$ and potassium metabisulphite increased water removal and moisture mobility in tomato slices during drying and influenced the drying kinetics of tomato and their dehydration ratio which was evident by changing in texture of dip treated tomatoes. In comparison with these pre treatments, control samples showed higher final moisture content $(6.9 \%$ with dehydration ratio 15.50 ) even with one hour longer period of dehydration process. Similar observations were reported by Olorunda et al. (1990). The fat contents of tomato powder treated with $\mathrm{CaCl}_{2}+\mathrm{KMS}$ had higher (3.9\%) fat than the others because of its lowest moisture content (Table 3). The same fat content $(2.8 \mathrm{~g} / 100 \mathrm{~g})$ was observed in both samples pre-treated with $\mathrm{KMS}$ and $\mathrm{CaCl}_{2}$ independently. The protein content of the different samples treated with $\mathrm{KMS}, \mathrm{CaCl}_{2}, \mathrm{KMS}+\mathrm{CaCl}_{2}$ and control were $12.6 \%, 13.1 \%, 13.9 \%$ and $12.4 \%$, respectively. The protein content of the sample treated with $\mathrm{KMS}+\mathrm{CaCl}_{2}$ was higher (13.9\%) than the other samples. Changes in protein content might be related to reactions. i.e., non-enzymatic browning which was found to be more in control samples and less in $\mathrm{CaCl}_{2}+\mathrm{KMS}$ treatment. Narsing Rao et al. (2008) observed that protein content of tomato powder was $12.65 \%$. Sample treated with 
$\mathrm{KMS}+\mathrm{CaCl}_{2}$ contains higher ash content $(10.72 \mathrm{~g} / 100$ g) while sample treated with $\mathrm{CaCl}_{2}$ showed lower ash content $(10.21 \mathrm{~g} / 100 \mathrm{~g})$. The higher crude fiber content $(6.5 \mathrm{~g} / 100 \mathrm{~g})$ was observed in $\mathrm{KMS}+\mathrm{CaCl}_{2}$ treated sample and the lower crude fiber was observed in control sample $(5.9 \mathrm{~g} / 100 \mathrm{~g})$. Narsing Rao et al. (2008) reported that the crude fiber content of tomato powder was $9.78 \mathrm{~g} / 100 \mathrm{~g}$, which was higher than that reported in the present study.

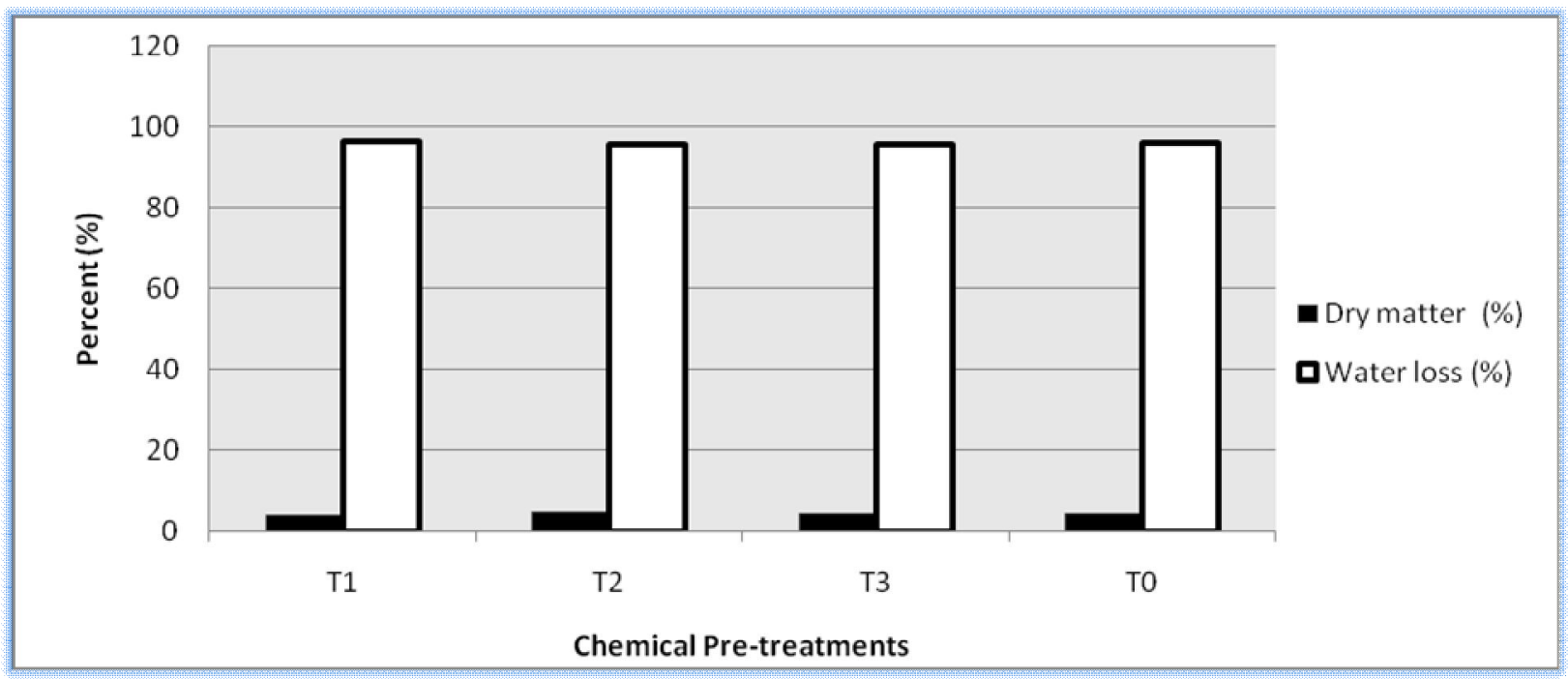

Fig. 2. Process efficiency of the different treatment (Percent recovery)

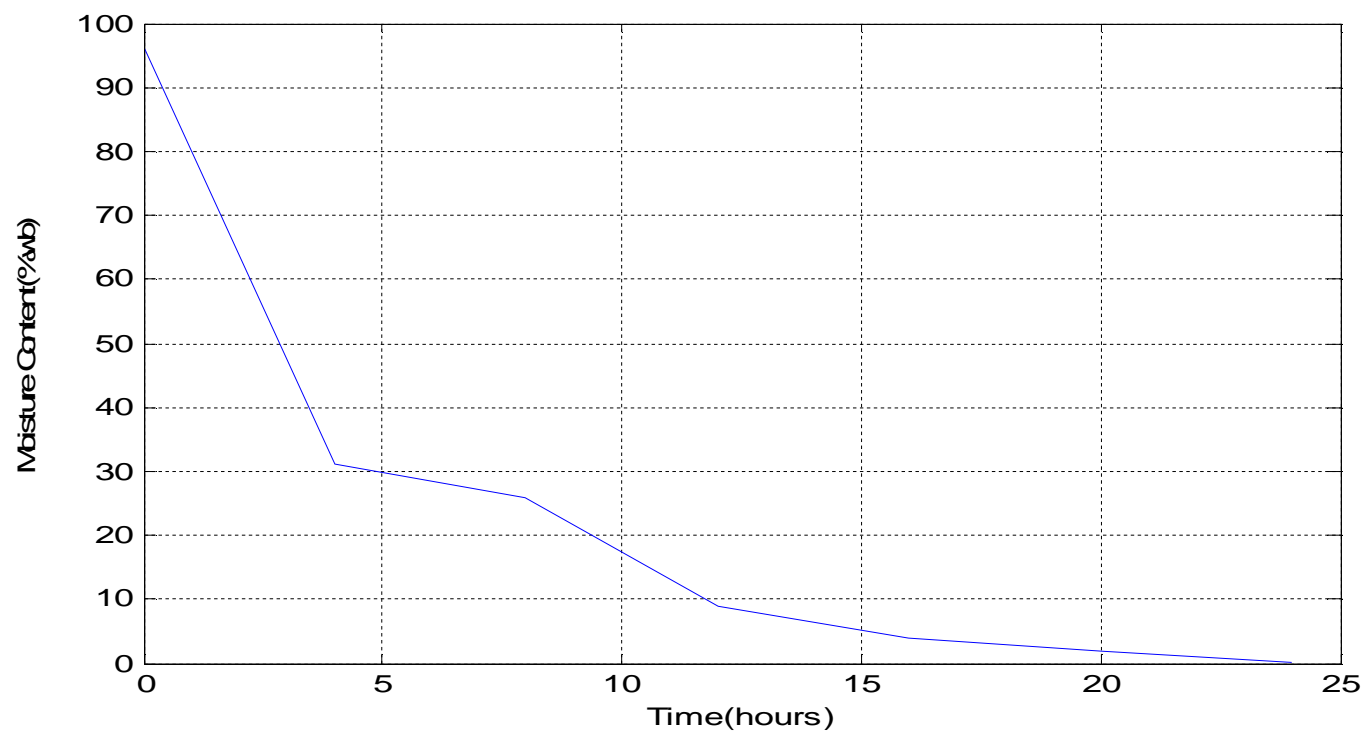

Fig. 3. Drying Curve for Tomatoes treated with $0.2 \% \mathrm{KMS}$ plus $1 \% \mathrm{CaCl}_{2}$ 


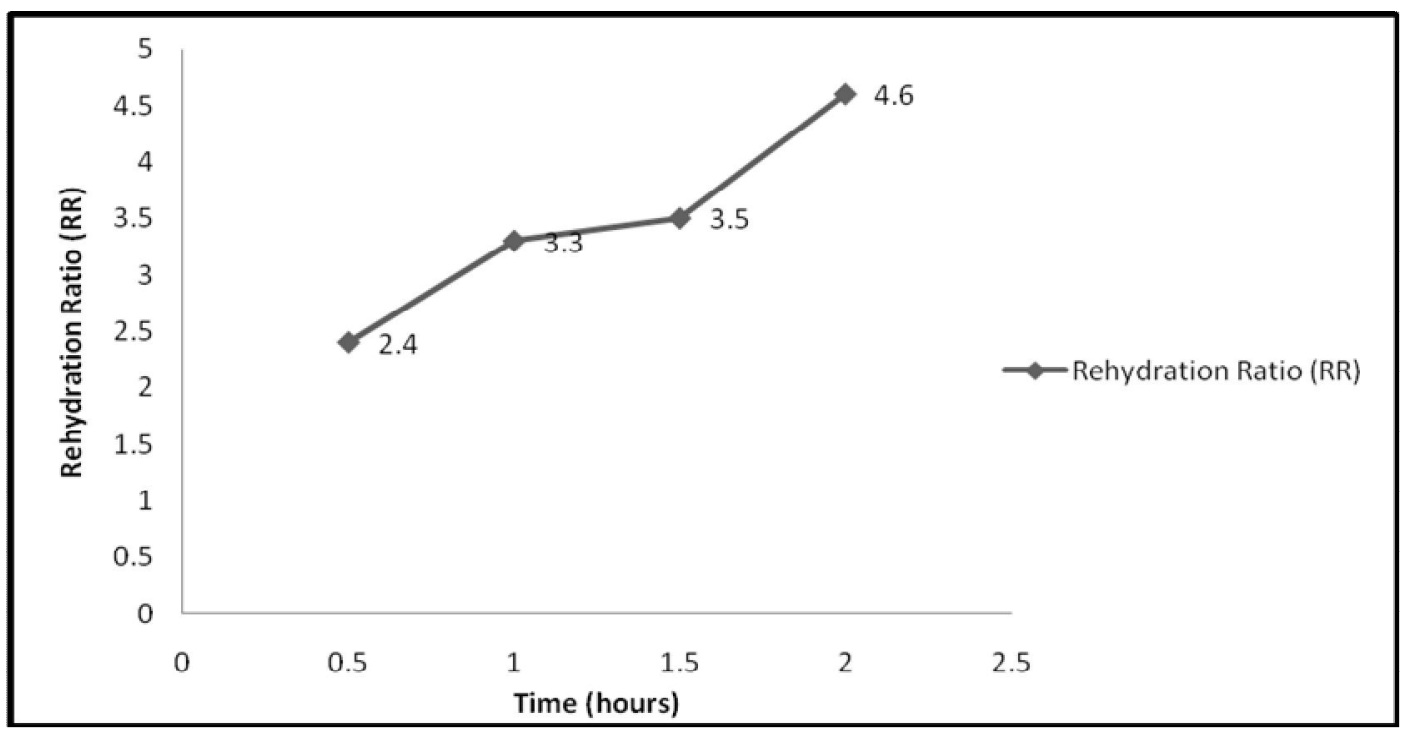

Fig. 4. Rehydration Ratio of dehydrated tomato $\left(\mathrm{T}_{3}\right)$ treated with $0.2 \% \mathrm{KMS}$ plus $1 \% \mathrm{CaCl}_{2}$

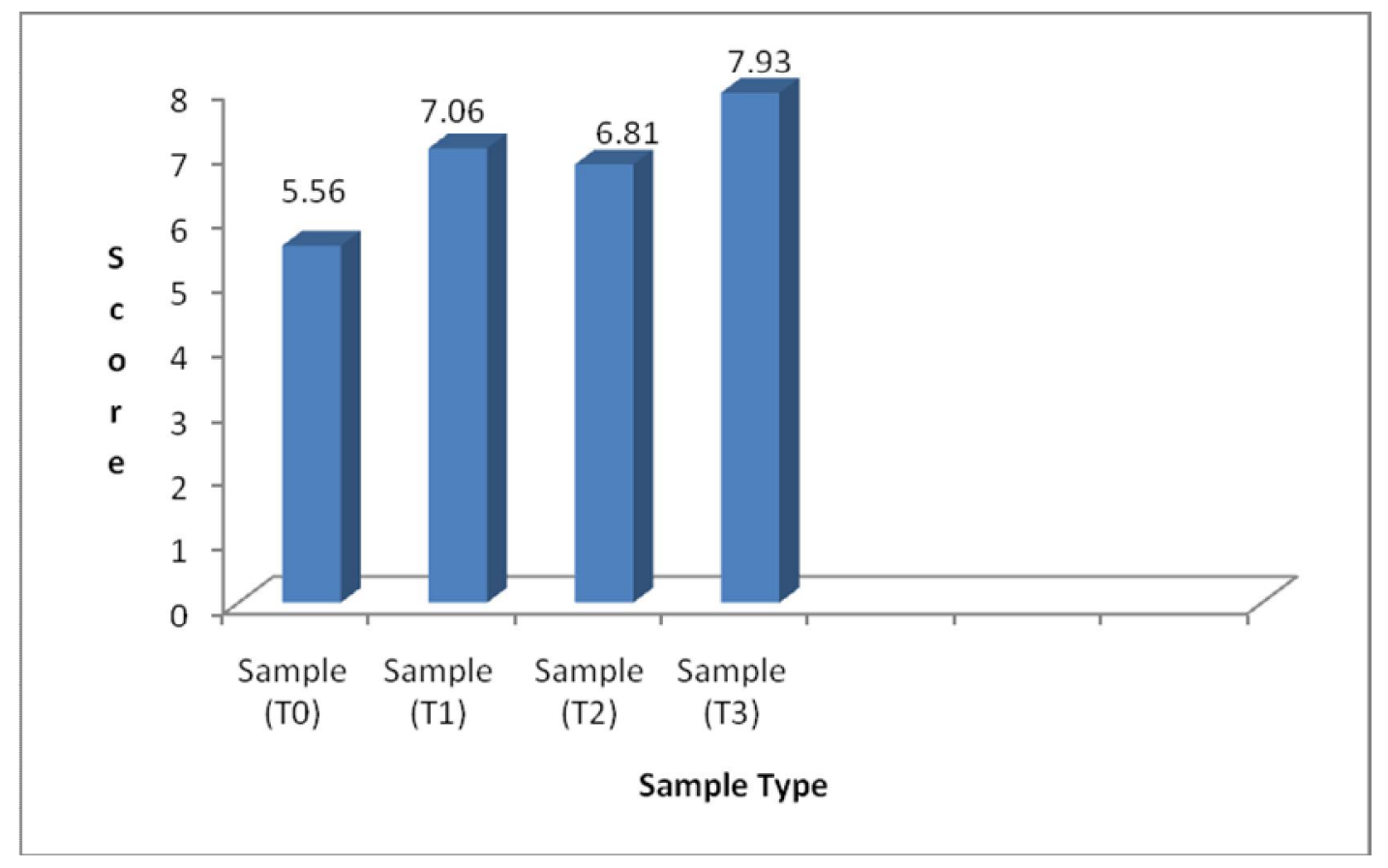

Fig. 5. Acceptability of color preference based on mean score 


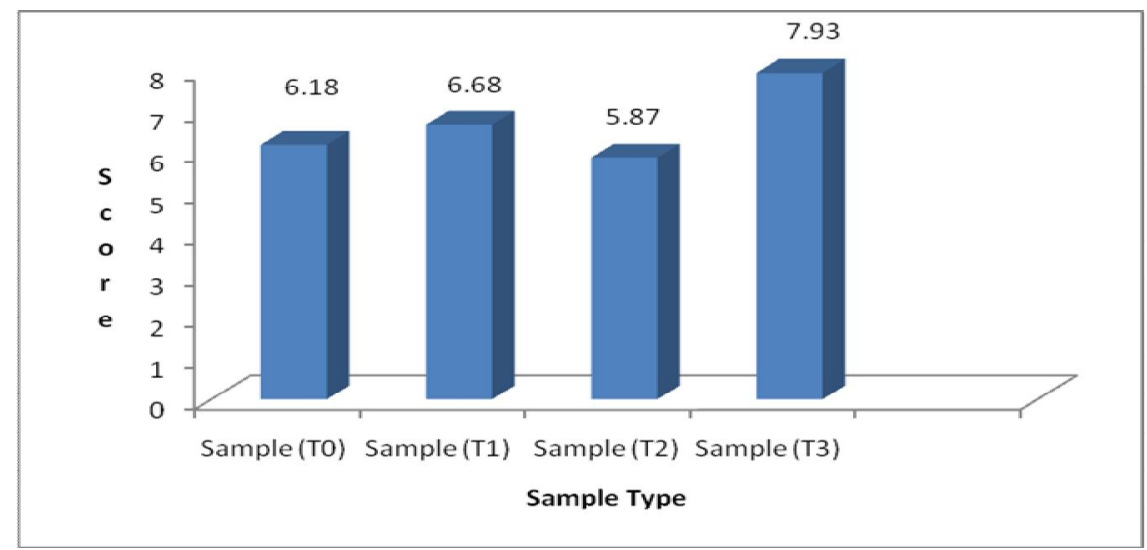

Fig. 6. Acceptability of flavor preference based on mean score

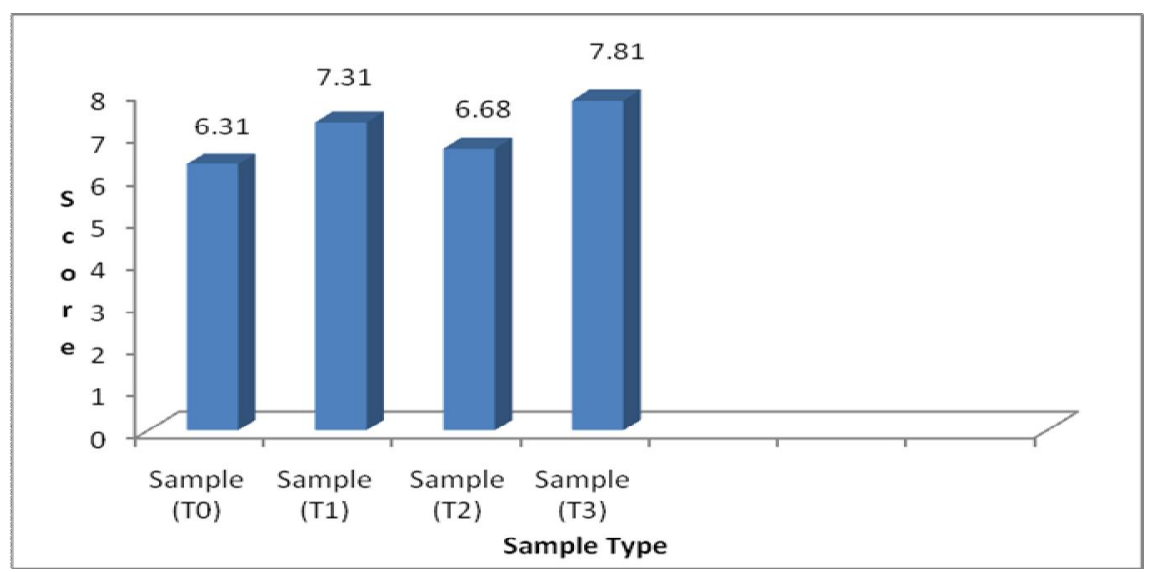

Fig. 7. Acceptability of texture preference based on mean score

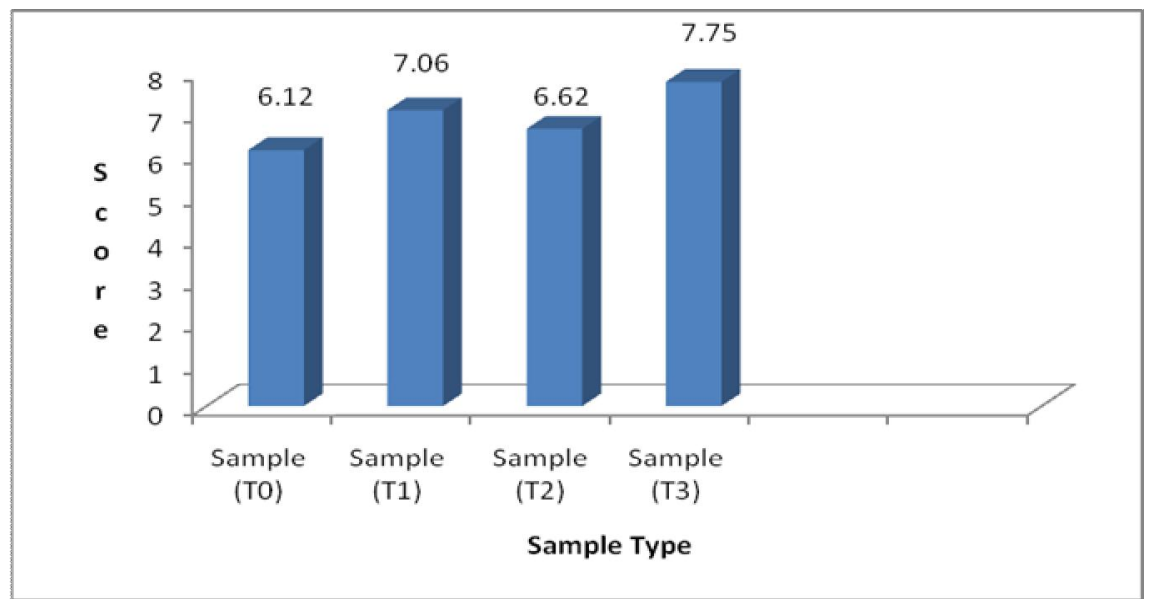

Fig. 8. Acceptability of overall preference based on mean score 
Calcium (336.672 mg/100 g), phosphorus (105 $\mathrm{mg} / 100 \mathrm{~g})$ and iron $(12.23 \mathrm{mg} / 100 \mathrm{~g})$ contents in tomato powder are presented in Table 3. Narsing Rao et al. (2008) reported that the Calcium and iron were $212 \mathrm{mg} / 100 \mathrm{~g}$ and $7.5 \mathrm{mg} / 100 \mathrm{~g}$, respectively. The total Carotenoid content of tomato powder was 210 $\mu \mathrm{g} / 100 \mathrm{gm}$. A study reported that the total Carotenoids content (including $\beta$-carotene and lycopene) of cherry tomatoes dried at a temperature of $60^{\circ} \mathrm{C}$ was about $0.36 \mathrm{mg} / \mathrm{g}$. Furthermore, total Carotenoid content of hot-air-dried pumpkin and carrot at $60^{\circ} \mathrm{C}$ were $0.14 \mathrm{mg} / \mathrm{g}$ and $1.1 \mathrm{mg} / \mathrm{g}$ respectively. Data presented in table 3 expressed that the vitamin $\mathrm{C}$ content of tomato powder was 35.30 $\mathrm{mg} / 100 \mathrm{~g}$. Lavelli et. al. (1999) reported that the content of ascorbic acid decreased from $3300 \mathrm{mg} / \mathrm{kg}$ of dry matter in fresh dried tomatoes at temperature $80^{\circ} \mathrm{C}$. Toor and Savage (2006) investigated that drying tomatoes at $42^{0} \mathrm{C}$ during 18 hours led to ascorbic acid losses between $17-27 \%$ according to tomato varieties.

The sugar contents in all pre-treated tomato samples were found to be higher than the control sample. Calcium Chloride $\left(\mathrm{CaCl}_{2}\right)$ along with potassium metabisulphite (KMS) pre-treated samples showed higher sugar content $(49.1 \mathrm{~g} / 100 \mathrm{~g})$ followed by $\mathrm{CaCl}_{2}$ which was $48.7 \mathrm{~g} / 100 \mathrm{~g}$. The lowest value was $48.1 \mathrm{~g} / 100 \mathrm{~g}$. The changes in sugar content may be related to two reactions. i.e., non-enzymatic browning which was found to be more in control samples and less in $\mathrm{CaCl}_{2}+\mathrm{KMS}$ treated sample. The results obtained in our study are in a good agreement with those reported by Gupta \& Nath (1984) and Gallali et al. (2000). From the Table 3, the sample pre-treated with potassium metabisulphite sample showed slightly more acidity $(6.28 \%)$ as compared to the control sample $(6.12 \%)$ while tomato powder pretreated with $\mathrm{CaCl}_{2}$ had lower acidity $(5.86 \%)$. Similar observation has been reported by Okanlawon (2002). Drying methods carried out by cabinet drier indicate higher acidity in samples, which are supposed to be related to the partial fermentation, occurred in some trials, due to longer time consumption and pectic enzyme activity in first hours of the drying process.

Rehydration is the phenomenon that decides the effectiveness of the final product. The result of rehydration of the chemically treated samples $\left(\mathrm{T}_{3}\right)$ is given in Fig. 4. It is clear from Fig. 4 that the rehydration ratio is significantly affected by chemical pretreatment; gradually increased with time and water uptake. The behavior of rehydration ratio of osmotically dehydrated carrot cubes was explained by Singh et al. (2007) on the basis that, the osmotically pretreated samples contain 8-12\% solute which got infused during osmotic dehydration and leached in to water during rehydration process without contributing to the rehydrating process

\section{Sensory evaluation of tomato powder}

The degree of difference among the samples was compared by Dancan's Multiple Range Test (Table 4) and the graphical presentation of scores for color, flavor, texture and overall acceptability are given in Figure 5 to 8 . Sample $\left(\mathrm{T}_{3}\right)$ gave the highest score in respect of colour, flavor, texture and overall acceptability followed by other samples. The Least Significant Difference (LSD) is the highest between [samples $\left(\mathrm{T}_{3}\right)$ ] texture and overall acceptability. It indicated that the tomato powder prepared from sliced with KMS treatment is highest in quality aspect. A two way analysis of variance (ANOVA) was carried out for color, flavor, texture and overall acceptability preference and results revealed that there were significant $(\mathrm{p}<0.1)$ differences in color, flavor, texture and overall acceptability among the tomato powder. In case for color preference, the color of different samples of tomato powder was not equally acceptable. As shown in Table 4, the sample $\left(\mathrm{T}_{0}\right)$ secured the lowest score (5.563) for the color preference than other samples. Sample $\left(\mathrm{T}_{3}\right)$ secured the highest score (7.93). As shown in Table 4 for flavor preferences, the sample $\left(\mathrm{T}_{2}\right)$ secured the lowest score (5.875) for the flavor preference. Sample $\left(\mathrm{T}_{3}\right)$ secured the highest score (7.93). In case for texture, the sample $\left(\mathrm{T}_{3}\right)$ is secured the highest score (7.81) for the texture preference while sample $\left(\mathrm{T}_{0}\right)$ secured the lowest score (6.31). The overall acceptability of different samples of tomato powder was equally acceptable as shown in Table 4.

\section{Conclusions}

The cabinet drying technique was applied for dehydration of tomato slices at $60^{\circ} \mathrm{C}$ for $24 \pm 2$ hours. $\mathrm{CaCl}_{2}$ increased water removal rate than the other pretreatment during dehydration and slightly brown color was developed in the control sample. KMS together with $\mathrm{CaCl}_{2}$ improved the quality of dehydrated slices. Finally, powder was prepared from dehydrated tomato slices and packed into normal polyethylene bags for storage study and utilization. $\mathrm{CaCl}_{2}$ revealed higher percent recovery of tomato powder $(4.60 \%)$ than $\mathrm{KMS}$ along with $\mathrm{CaCl}_{2}(4.36 \%)$ and control $(4.09 \%)$. However, KMS treated sample showed lowest percent recovery $(3.83 \%)$. The vitamin-C of the developed tomato powder was quite lower than fresh tomato. The lower value of vitamin$\mathrm{C}$ or the damage of vitamin during drying was primarily due to heat, oxidation and light. Sensory 
evaluation of tomato powder was carried out, there was no significant difference in regards to flavor, texture as well as overall acceptability among the samples but significant difference was observed in terms of color among the samples. KMS along with $\mathrm{CaCl}_{2}$ treated sample showed the better color than other samples.

\section{Acknowledgements}

We acknowledge the financial support (NSICT Fellowship, 2011) from the Ministry of Science, information and communication Technology of Bangladesh. We also thank the IFST, Bangladesh Council of Science and Industrial Research, Dhaka.

\section{References}

AOAC, Association of Analytical Chemists.1984. Moisture in dried fruits. In: Williams S, editor. Official methods of analysis of the Association of Official Analytical Chemists. Arlington, Va.: AOAC. $415 \mathrm{p}$.

BBS. 2010. Statistical Yearbook of Bangladesh. Ministry of Planning, Government of the People's Republic of Bangladesh, Dhaka, Bangladesh.

Baloch, W. A., Khan, S. and Baloch, A. K. 1997. Influence of chemical additives on the stability of dried tomato powder. Int. J. Food Sci. and Technology, 32(2): 117-120

Charanjeet, K.; George, B.; Deepa, N.; Singh, B. and Kapoor, H. C. 2004. Antioxidant status of fresh and processed tomato. J. Food Sci. and Technology, 41(5): 479-486.

Collins, J. L.; Sidhu, H. S. and Mullins, C. A. 1997. Drying tomatoes through osmotic treatment and dehydration. Tennessee Agricultural Sci., 182: 24-27.

Delia, B.; Rodriguez-Amaya, and Kimura, M. 2004. Harvest Plus Handbook for Carotenoid Analysis. International Center for Tropical Agriculture (CIAT). Series-2. pp. 8-52.

ECOM. Ecom Canada Ingredients. 1997. Available from: http:// ecomcanada.com/tomato.html. Accessed 2001 Feb 3.

Ghavidel, R.A. and Davoodi, M.G. 2010. Studies on Physiochemical Properties of Tomato Powder as Affected by Different Dehydration Methods and Pretreatments. World Academy of Science, Engineering and Technology. 69.

Gallali, M. Y.; Abujnab, Y. S. and Bannari, D. F. 2000. "Preservation of fruits and vegetables using solar drier: a comparative study of natural and solar drying, III; chemical analysis and sensory evaluation data of the dried samples," Renewable Energy, 19: 203-212.

Gisele, A. C.; Roberto, H. M. and Carlos, A. S. L. 2004. Quality of dried tomato pretreated by osmotic dehydration, antioxidant application and addition of tomato concentrate - Proceedings of the 14th International Drying Symposium (IDS 2004), São Paulo, Brazil, 22-25 August 2004, C: 2207-2215.

Gupta, R.G. and Nath, N. 1984. Drying of tomatoes. $J$. Food Sci. and Technology, India, 21:372-376.

Hawlader, M. N. A.; Uddin, M. S.; Ho, J. C. and Teng, A. B. 1991. Drying characteristics of tomatoes. J. Food Eng., 14: 259-268.

Hema, P. P.; Sudha. P. and Devibala, B. 2007. Studies on the effect of chemical treatments on dehydrated tomato, J. Food Eng., 54: 141-146.

Lane, J. H. and Eynon, L. 1923. Volumetric determination of reducing sugars by means of Fehling's solution, with methylene blue as internal indicator. ISI XXV : 143-149.

Latapi, G. and Barrett, D. M. 2006. Influence of predrying treatments on quality and safety of sundried tomatoes. Part II. Effects of storage on nutritional and sensory quality of sun-dried tomatoes pretreated with sulfur, sodium metabisulfite or salt. J. Food Sci., 71(1):S32-37

Lavelli, C.W.; Hippeli, S.; Peri, C. and Elstner, E. F. 1999. Evaluation of radical scavenenging activity of fresh and air dried tomatoes by three model reactions, J. Agri. and Food Chemistry, 47: 3826-3831.

Levi, A.; Ben-Shalom, N.; David, P. and David, R. S. 1988. Effect of blanching and drying on pectin constituents and related characteristics of dehydrated peaches. J. Food Sci. 53(4):1187-90.

Lewicki, P.P. 1998. Some remarks on rehydration of dried foods. J. Food Eng., 36:81-7.

Lewicki, P. P.; Vu L. and Hoaand Pmaranska-Lazuka, W. 2002. Effect or pretreatment on convective drying of tomatoes. J. Food Eng., 54: 141-146.

Narsing, R. G. Prabhakara R. P. G.; Jyothirmayi, T.; and Rao, D. G. 2008. Chemical composition, standardization and storage studies on raw mango chutney powder. J. Food Sci. and Technology, 45 (5): 436-438.

Okanlawon, S. O.; Ibrahim, M. H. and Oyebani, A. O. 2002. Effect of pre drying treatment on the storage of dried tomato, Tropical Sci. 42: 40-41.

Okos, M.R.; Narishman, G.; Singh, R.K. and Weitnauer, A.C. 1992. Food dehydration. In: Handbook of food engineering. New York: Marcel Dekker. pp. 437-562.

Olorunda, A. O.; Aworh, O. C. and Onucha, C. N. 1990. Upgrading quality of dried tomato: Effects of drying methods, conditions and pre-drying 
treatments. Journal of the Science of Food and Agriculture, 52(4), 447-454.

Pazyr F.; Yurdagel U.; Ural, A. and Babalyk, O. 1996. Factors affecting sulfur dioxide absorption in tomatoes prepared for sun drying. In: Processing of sun-dried tomatoes. Seminar notes. BornovaIzmir, Turkey: Food Engineering Dept., Ege Univ. pp. 46-55.

Purseglove, J. W., Brown, E. G., Green, E. G. and Robbins, S. R. J. 2001. Vegetables crops. Copublished in the United States with John Witey and sons. Inc. New York. 2(8):447-462.

Rangana, S. 1992. Handbook of Analysis of Quality Control for Fruit and Vegetable Products. $2^{\text {nd }} E d$. TATA McGraw-Hill pub. Co. Ltd. New Delhi.

Roy, S.K. and Choudary, B. 1972. Studies on physico-chemical characteristics of a few varieties of tomatoes (Lycopersicum esculentum Mill) in relation to processing J. Food Sci. and Technology, 9: 151-154.

Sharfuddin, A.F.M. and Siddique, M.A.S. 2000. Shabjee Bighan. $1^{\text {st }}$ Dd. Mrs. Hasina Akter Beauty. Bangladesh Agricultural University. Mymensingh. 11p.
Sebii A. A.; Abdoul-Enein, S.; Ramadan, M. R. I. and El-Gohary, H.G. 2002. "Experimental investigation of an indivect type natural convection solar dryer," Energy Conversion and Management, 43: 225-226.

Shi, J. X.; LeMaguer, M.; Kakuda, Y.; Liptay, A. and Niekamp, F. 1999. Lycopene degradation and isomerization in tomato dehydration. Food Research International, 32(1), 15-21.

Stone, C.V. 1985. Sensory Evaluation Prattices. Florida: Academic Press 311p.

Toor, R.K. and Savage, G.P. 2006. "Effect of semidrying on the antioxidant conponents of tomatoes", Food Chemistry, 94: 90-97.

Valley Sun. 2000. Sun-dried tomato-the valley sun difference. Newman, Calif. Available from: http://www.valleysun.com. Accessed 2001 Jan 1.

Zanoni, B.; Peri, C.; Nani, R. and Lavelli, V. 1999. Oxidative heat damage to tomato halves as affected by drying. Food Research International, 31(5), 395-401. 